\title{
Cultural problems of education in pedagogical research of Ukrainian and Polish scientists
}

\author{
Multiculturalism is the wealth and an opportunity \\ to develop every society and every individual, \\ but it can also be a source of conflict, wars, tragedies. \\ The means of preparing people for life \\ in a multicultural world should become an education
}

Tadeusz Lewowicki

Streszczenie: W artykule dokonano analizy badań pedagogicznych prowadzonych przez ukraińskich i polskich naukowców, dotyczących problemów kulturologicznych edukacji. Wykazano, że na Ukrainie problemy kulturologiczne edukacji stają się coraz bardziej powszechne, odbywa się stopniowe rozgraniczenie treści pojęć edukacji wielokulturowej i międzykulturowej, problemy edukacji międzykulturowej coraz częściej znajdują odzwierciedlenie w badaniach naukowych i praktyce dydaktycznej.

Ważne znaczenie w rozwoju zagadnień kulturologicznych w badaniach pedagogicznych ma rozwój nowego kierunku zintegrowanych badań naukowych na Ukrainie - oświatologii oraz jej części składowej - edukacji kulturologicznej. Badania polskich naukowców opierają się na znaczących osiągnięciach polskiej nauki pedagogicznej i praktyce w zakresie wdrażania podejścia kulturologicznego w edukacji. Szczególną uwagę w badaniach polskich naukowców zwraca się na edukację wielokulturową oraz międzykulturową na pograniczu; na kształtowanie wielowymiarowej tożsamości człowieka; na różne aspekty teorii i metodyki edukacji międzykulturowej. Do rozwiązywania problemów edukacji wielokulturowej w Polsce przyczynia się wyraźne rozgraniczenie pojęć edukacji wielokulturowej i międzykulturowej, określenie na poziomie ustawodawczym pojęć mniejszości narodowej, grupy etnicznej i in.

Słowa kluczowe: edukacja wielokulturowa, edukacja międzykulturowa, wielowymiarowa tożsamość, mniejszość narodowa, grupa etniczna 
Development of culturology of education is important in view of the demands, needs and living conditions of the modern open multicultural society. Firstly, there is a need to implement the principle of multiculturalism in educational policy and to prepare for productive human intercultural dialogue within each multi-ethnic country. Secondly, globalization and integration processes in the world and vast computerization require an ability to live among others, to cooperate with those who are different in culture, traditions, religion, language, etc., as in the era of globalization, there is significant expansion of the range of occupations connected with intercultural communication. Today, migration of population on the planet, creating global communication networks and corporations, the implementation of cross-cultural projects lead to the fact that every professional activity is carried out in a multicultural context.

Ukraine is inhabited by citizens of more than 100 nationalities, who together make up the multimillion population of Ukraine, and the Declaration of Rights of Nationalities guarantees them political, economic, social and cultural rights equal to Ukrainians (Article 1), free use of native languages in all spheres of public life (Article 3), the right to profess their religion, to use their national symbols, celebrate their national holidays (Article 4) (Declaration of Rights of Nationalities of Ukraine).

The national population of Ukraine is dominated by Ukrainians, whose population size is $77.8 \%$ of the total population. The largest part of Ukrainians lives in Ternopil (96.8\%) and Volyn (94.6\%) regions, the smallest - in Crimea (25.8\%), Luhansk (51.9\%), Donetsk (50.9\%), Odessa (54.6\%) regions.

What is understood by minority under the laws of Ukraine is a group of Ukrainian citizens who are not of Ukrainian nationality, show a sense of national identity and unity (Declaration of Rights of Nationalities of Ukraine). According to the last census (2001) national minorities in Ukraine amounted to 27.3\% of the total population. The largest ethnic minority is the Russian one (17.3\%).

Every other ethnic minority (Jews, Belarusians, Moldovans, Bulgarians, Poles, Hungarians, Romanians, Greeks, Tatars, Armenians, Gypsies etc.) constitutes less than $1 \%$ of the total population.

Poles $(0.3 \%)$ are one of the oldest national minorities of Ukraine. The total number of Poles in Ukraine is steadily declining. The peculiarity of the modern settlement of Poles in Ukraine is that most of them live in areas of long-standing residence - in Volhynia, Podolia, Galicia, particularly in Zhitomir, Khmelnitsky, Lviv regions and in Kyiv (65.5\% of the total in Ukraine). 
The territory of Ukraine is also a home to many different ethnic groups.

What is understood as an ethnic group or subethnos in Ukraine is a community of people belonging to a particular ethnic group and by keeping the traditional elements of consumer culture (clothing, housing, customs, rituals, folklore, folk music, arts and crafts), dialect differences in language forms a historical and cultural community.

For many centuries, in the Ukrainian ethnic territories different ethnic groups of Ukrainians have been formed: Lemko, Dolinians, Jaunty, hutsuly pokutyany, opolyany, Podilians, clearing Volhynians, Batiuk, holmschaky, pidhiryany, pidlyashuky, Pinchuk Polishchuky, polovyky, Cherkassy, Poltava, Kyrdany, Sevruk, Slobodzhanians, steppe, zadunaytsiv, Kubans, Donets and others. Among them, the largest and the most important in the creation of the state were Polyany (Kiev, Rus) (Ukrainian ethnic groups).

Urbanization and rapid economic development have contributed to cultural and social integration of these groups with other populations of Ukraine, mostly by smoothing their specific characteristics. Ethnic groups of Ukrainian ethnicity were best preserved in the Ukrainian Carpathian Mountains and Transcarpathian Region, in particular the groups of highlanders - Jaunty, Hutsuly, Lemkies.

The problems of the multicultural society in Ukraine are reflected in educational theory and practice. The leading purpose of this article is to analyze educational research of Ukrainian scholars that addresses the problem of cultural education and to conduct a comparative analysis of the studied problems with those which Polish scientists focus on.

\section{The characteristics of Ukrainian studies}

It can be concluded that not many works of Ukrainian scientists are devoted to culturological problems of education. Thus, during the years of independence of Ukraine (from 1991 to 2013) 2448 teaching science theses have been prepared and successfully defended. From these works only 61 (2.49\%) explored the problems of cultural education. The analysis of the studies over the years shows that from 1991 to 1998 two works were only done on this issue, and from 2001 to 2013 - 60 works. The greatest amount of research has been conducted for the last two years.

The analysis was conducted of some research of Ukrainian scientists dedicated to culturological problems of education, which has been performed with- 
in the leading research and teaching areas of Ukraine, namely: the theory and history of pedagogy, theory and methods of education, theory and methodology of professional education theory and teaching methodology, theory training.

The analysis showed that the cultural aspects of vocational training, training and education of youth, are the most frequent in the research $(29.5 \%$ of 61 theses).

The research into the theory and practice of cultural training of future specialists in different areas comprises: formation of cultural competence, including engineers, farmers, teachers; modernizing the content of cultural disciplines in higher education; designing the content of textbooks based on cultural approach; implementation of the linguo-cultural approach to education of minorities; education of youth in the cultural approach; development of different types of culture (aesthetic and political) and others. Most of these studies - over a half (55.5\%) have been completed within the subject "theory and methodology of vocational education." Some most significant works will be analyzed.

O. L. Shevnyuk in his work "Theory and practice of cultural education of future teachers in high school" examines the content of pedagogical phenomenon of cultural education of future teachers as a process and outcome mastered by students on the universal basis of human culture and on the basis of integral, axiological, antropological, multicultural and professional purposes. This is justified by the educational system of cultural education of students in higher educatin based on ensuring the effectiveness of the processes of cultural generalization of knowledge and skills in the field of professional activity of teachers and their involvement in the activities of the cultural self ${ }^{1}$.

In A. I. Zhornova's work "Theoretical and Methodological Basis for the Formation of Cultural Ceativity of University Students", the concept of cultural creativity of university students constitutes the theoretical basis for improving their professional training ${ }^{2}$. The leading idea of the concept is the need to develop students' awareness of being cultural creators and of their professional activity as a work of culture which reflects the accumulated tendencies of the new production paradigm.

1 О. А. Шевнюк: Теорія і практика культурологічної освіти майбутніх учителів у вищій школі: Аис. ... А-ра пеА. Наук: 13.00.04/О. А. Шевнюк; Нац. ПеА. Ун-т ім. М. П. Арагоманова. - К., 2004. - 555 с.

2 О. І. Жорнова: Теоретико-методологічні засади формування куль-туротворчості студентів університетів: Аис. ... А-ра пеА. наук: 13.00.04/О. I. Жорнова; Терноп. нац. пеА. ун-т ім. В. Гнатюка. - Т., 2007. - 455 с. 
Another study of global education of students completed by E. A. Zelenova $^{3}$ draws a lot of attention. In this paper, based on the cultural approach, the current methodological approaches to global education of students were analyzed, the theoretical foundations of global education were shown: philosophical (cosmism, the concept of sustainable development, Vernadsky's teaching about noosphere, the concept of dialogue between cultures and the world culture), psychological (interdisciplinary approach to teaching activities and the concept of mentality, especially the theory of cultural identification), educational (pedagogy of nonviolence and tolerance, noosphere, space education and education for sustainable development, the concept of school culture of dialogue, multicultural education theory, pedagogy of the world culture). It should be noted that the main medium of global education of students is identified as university space, multicultural dialogue, academic freedom and universal knowledge, the cultural centre of accumulation and transmission of human and national values.

The culturological basis for the development of national education system and educational thought is given much less attention. Some important research which reveals the cultural foundations of education and educational thought in the Donetsk region in the late $19^{\text {th }}$-early $20^{\text {th }}$ century was done by L. Terskyh ${ }^{4}$. What was proved in this paper for the first time were the cultural origins and foundations of the education system and educational thought in the Donetsk region during this period; the research also comprised the integral cultural, historical and pedagogical analysis of different types of schools, general characteristics of educational ideas and educational activities of leaders of education, science and culture.

What is also worth notice is the study of the theory and methods of teaching conducted by J. M. Hawryluk, in which the method of implementation of cultural content is explored in the course of the history of Ukraine for 8-9 years of study in high school ${ }^{5}$.

3 Є. А. Зеленов: Теоретико-методологічні основи планетарного виховання студентської молоді: Аис. ... А-ра пеА. наук: 13.00.07/Є. А. Зеленов; СхіАноукр. нац. ун-т ім. В. Аахя. - Ауганськ, 2009. - 540 с.

4. $\Lambda$. О. Терських: Культурологічні основи розвитку системи освіти та педагогічної думки на Аонеччині в кіниі ХІХ-початку XX століття: Аис. ... канА.

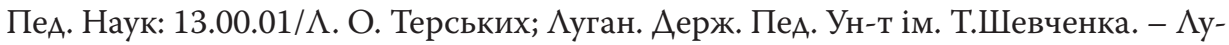
ганськ, 2001. - 520 с.

5 Ж. М. Гаврилюк: Методика реалізації культурологічного змісту в курсі 
The problems of multicultural education are reflected in more than a half (59.01\%) of the research on cultural issues (61). However, this represents only $1.47 \%$ of the total number of educational studies in Ukraine (since 1991).

The issues dealt within these studies relate to the following aspects of multicultural education: training specialists to interact in the educational process in terms of multiculturalism; pedagogical technologies of multicultural competence of experts, referring also to international students; multicultural education teachers; preparing future teachers for multicultural education of students; formation of national consciousness of students; problems of multicultural education in foreign countries; focus on the content of school textbooks on multicultural education in schools; axiological aspects of multicultural education; preservation of the national identity of higher education in Ukraine. Here are some examples of such studies.

N. V. Yaksy considers: teachers training to interact in the educational process in terms of multiculturalism in the Crimean region, formation and development of the Ukrainian system of professional training of teachers on the basis of interculturalism; criteria for readiness of teachers for intercultural activities $^{6}$.

Within the theory and methodology of education attention should be drawn to the work of V. Borisov dedicated to the formation of national consciousness of students ${ }^{7}$. The author has shown that national education is possible in secondary and higher education institutions in the case of implementation of intercultural education programs and areas of educational work which take into consideration the principles of multiculturalism and the input into the content of educational work exploring distinctive cultural worlds.

O. A. Iwashko in his research within the direction "Theory and History of Education", as the first, comprehensively investigated the issue of multicultural education in Poland. The author reveals the historical, socio-political, so-

історії Украӥни 8-9 класах: Аис. ... канА. ПеА. Наук:13.00.02/Гаврилюк Жанна Миколаївна; Ін-т пеАагогіки НАПН України. - К., 2012. - 264 с.

6 Н. В. Якса: Професійна підготовка майбутніх учителів до взаємодії субъєктів освітнього процесу в умовах полікультурності Кримського регіону: Аис. ... А-ра пеА. наук: 13.00.04/Н. В. Якса; Ін-т пеА. освіти і освіти Аоросл. АПН України. - K., 2009. - 574 c.

7 В. В. Борисов: Теоретико-методологічні засади фбормування національної самосвідомості учнівської та студентської молоді: Аис. ... А-ра пеА. наук: 13.00.07/B. В. Борисов; Терноп. нац. пеА. ун-т ім. В. Гнатюка. - Т., 2006. - 540 с. 
cio-economic and educational and cultural preconditions for implementing the principles of multicultural education in schools of the country; the basic stages of implementing the ideas of multicultural education in Poland; the state of multicultural education in the Polish borderlands is also described as well as the features of the education of national minorities, returnees, immigrants, refugees, regional education, directions in incorporation of multicultural education experience of Poland in the education system of Ukraine ${ }^{8}$.

It should be stressed that O.A. Iwashko performed a comparative analysis of definitions in the scientific teaching of Ukrainian and Polish researchers as regards problems of multicultural education, analyzed the differences between the terms "multiculturalism" and "mizhkulturnist", "multicultural education" and "intercultural education" in Ukrainian and Polish educational theory and practice, the meaning of "borderland pedagogy", "regional education", "educational glocalization" in Polish education.

The issues of multicultural education are also considered in some studies on school education. In this context in L. E. Peretyaha's work the results are provided of theoretical and experimental studies on the formation of multicultural competence of younger students ${ }^{9}$.

In this paper, the essence of the concept of "multicultural competence" is explored, its structural components (cognitive, affective, operational, behavioral) and didactic conditions of multicultural competence of younger learners is defined, which is to ensure the integration of multicultural information with the main program material subject as well as providing interrelations of academic and extracurricular activities in the formation of multicultural competence. The criteria forming the main components of multicultural competence of younger learners include, in particular, cognitive (self-ethnic, ethno-cultural awareness of their ethnic culture and the culture of other ethnic groups, knowledge of multicultural terminology), affective (cognitive interest and desire to learn their ethnocultural heritage and of other ethnic groups; attitudes towards members of other ethnic groups), operational (information skills), behavioral (intercultural experience) criteria.

8 О. А. Івашко: Проблема полікультурної освіти у Республіці Польщу: Аис. ...канА. пеА. наук:13.00.01/Івашко О. А.; Київ. ун-т імені Бориса Грінченка. K., 2012. -260 c.

9 А. Є. Перетяга: Аидактичні умови фбормування полікультурної компетентності молодших школярів: Аис. ... канА. пеА. наук: 13.00.09/А. Є. Перетяга; Харк. нац. пеА. ун-т ім. Г. С. Сковороди. - Х., 2008. - 274 с. 
It should be noted that in recent years (since 2012) there have been some research on intercultural education in which the notion of multicultural and intercultural education are regarded as not equal (11.48\% of 61$)$. These studies represent $0.29 \%$ of the total number of educational research in Ukraine.

Topics of scientific research concern more the various aspects of professional training, including problems of formation of future professionals for intercultural communication; development of intercultural competence; learner-centered education of students in a social and cultural environment of university; methods of teaching intercultural communication.

It should be emphasized that in the studies of Ukrainian authors personal approach is seen as leading to the formation of cross-cultural competence of students, and socio-cultural environment of higher education institution as a decisive factor in personal cultural development of each student. It is also worth noting that the problems of multicultural and intercultural education are not yet understood as important by Ukrainian practicing teachers. Thus, the survey of 1006 teachers in six regions of Ukraine showed that only $1.76 \%$ of respondents are interested in these issues and would like to improve their knowledge and skills in intercultural interaction, communication, education, tolerant attitude of students to other cultures.

\section{Main directions in the research by Polish scientists}

In the theory and practice of teaching science, the problem of Polish multiculturalism and intercultural education is paid considerable attention. Courses on teaching cultural studies, intercultural pedagogy, intellectual culture, etc. are introduced in the university curriculum in the field of "Pedagogy". Tadeusz Lewowicki, a forerunner of the studies on multicultural and intercultural education in Poland, in his book "Education in multicultural environment - from assimilation to multicultural education and multidimensional identity" notes that in today's world the phenomenon of multiculturalism becomes inclusive ${ }^{10}$. In this regard, many multicultural societies have implemented various models of education. Education, especially school, leads to the assimilation of minority groups and their parallel existence in learning

10 T. Lewowicki: Oświata w warunkach wielokulturowości - od asymilacji do edukacji międzykulturowej $i$ wielowymiarowej tożsamości. W: W. Kremień, T. Lewowicki, J. Nikitorowicz, S. Sysojewa (red.): Edukacja w społeczeństwach wielokulturowych. Warszawa 2012, WSP ZNP w Warszawie, UwB. 
and education. However, the scientist points out that this process does not contribute to the integration of these groups. Multicultural education, according to T. Lewowicki, experiences a crisis nowadays. Therefore, long-term positive social change and integration are associated not with multicultural education but intercultural education.

The ideas of intercultural education and its difference from multicultural education are considered in other works of the author, such as "Multiculturalism and Education - tradition and the origins of multicultural education", "Multiculturalism and Education - Perspectives for Intercultural Education", "Teachers in multicultural environment - challenges and success factors", "Multiculturalism and Education - common problems in Polish and Ukrainian contexts", "The experience of multicultural education and intercultural education perspective and pedagogy " and the works of others ${ }^{11}$.

Special attention to culturological problems of education as a whole, including aspects of multicultural and intercultural education, is paid in wellknown Polish cultural studies by Janusz Gajda. In his work "Multiculturalism in the context of current challenges in humanistic and anthropological education", the scientist reveals the profile and the complex nature of contemporary culture, the main gaps in multicultural and intercultural education, including - the appeal only to postmodern philosophy, or culture and ignoring other areas, such as pedagogical culture ${ }^{12}$. This scientist stresses the usefulness of humanistic and anthropological concept of education as the foundation of the modern trend of pedagogy - pedagogical culture, which advocates an alternative direction to multicultural education.

Also it is interesting to show such aspects of Polish studies like multiculturalism of work and the local environment. Professor Henryk Bednarczyk reveals this problem, based on the experience of European cooperation in education $^{13}$. In his work he gives the results of studies on the implementation

11 Tamże.

12 J. Gajda: Wielokulturowość wciąż aktualnym wyzwaniem edukacji humanistyczno-antropologicznej. W: W. Kremień, T. Lewowicki, J. Nikitorowicz, S. Sysojewa (red.): Edukacja w społeczeństwach wielokulturowych. Warszawa 2012, WSP ZNP w Warszawie, UwB.

13 H. Bednarczyk: O wielokulturowości pracy i środowiska lokalnego - z doświadczeń edukacyjnej wspótpracy europejskiej. W: W. Kremień, T. Lewowicki, J. Nikitorowicz, S. Sysojewa (red.): Edukacja w społeczeństwach wielokulturowych. Warszawa 2012, WSP ZNP w Warszawie, UwB. 
of European projects in the village Sytsyna and reveals features of non-formal education in the professional work, he examines how rural areas provide the activity in the age of Internet and globalization, gives some examples of multiculturalism and the perception of other cultures in Poland and Europe countries. Interestingly, H. Bednarczyk draws attention to the educational needs concerning IT and effects of adult education in Europe, particularly in the context of cultural transmission of experience between generations.

It should be stressed that in research on multicultural and intercultural education of Polish scientists it is emphasized that the mission of higher education is to ensure the development of academic mobility and that it can be efficiently implemented on the basis of intercultural education. Higher education is one of the areas of social and economic life which is developing very dynamically. Education, as noted by Barbara Grabowska, plays an important role in the development of society, therefore the demand for higher education increases ${ }^{14}$. In the Republic of Poland in the last 20 years there has been nearly a fivefold increase in the number of students. According to B. Grabowska, this was due to the decline in the quality of higher education. Exploring the development of higher education in social change, the researcher points out the need for a sense of national identity of young people in the borderland.

The latest works of Polish scientists concern the problem of the formation of multi-dimensional human identity. Intercultural education, according to T. Lewowicki, is designed to promote understanding of the contemporary identity ${ }^{15}$. Traditionally, identity is associated mainly with nationality, state, religion. Now there is the increasingly important trend of combining different dimensions of identity - family, local, regional, national or ethnic, national and civil, religious, philosophical, European.

Polish scientists have paid attention to: the issues of identity formation as the development of the sense of national identity of borderland residents,

14 B. Grabowska: Szkolnictwo wyższe w Polsce w świecie mobilności i zróżnicowania kulturowego. W: T. Lewowicki, W. Kremień, W. Ogniewjuk, S. Sysojewa (red.): Oswitni reformi: misja, dijsnist', refleksja. Kyjiw 2013, Ministerstwo oswiti i nauki Ukraini, NAPN Ukraini, Wyższa Szkoła Pedagogiczna ZNP w Warszawie, Kyjiwskij uniwersytet imieni Borisa Grinczenka.

15 T. Lewowicki: Oświata w warunkach wielokulturowości - od asymilacji do edukacji międzykulturowej $i$ wielowymiarowej tożsamości. W: W. Kremień, T. Lewowicki, J. Nikitorowicz, S. Sysojewa (red.): Edukacja w społeczeń-stwach wielokulturowych. Warszawa 2012, WSP ZNP w Warszawie, UwB. 
including the Polish-Lithuanian ones (Urszula Namiotko); identity of the students in the situation of cultural change (Emilia Żyłkiewicz-Płońska); cultural identity as an essential element and educational strategy in multicultural relations (Marian Nowak); social identity - a barrier or assistance in creating positive intercultural relations (Jolanta Miluska); intercultural education as a way of self-identification in society (Jolanta Suchodolska); a sense of cultural identity of students (Gabriela Piechaczek-Ogierman, Izabela Krzemińska-Woźniak); diagnosis of the socio-cultural identification in the context of intercultural education (Mirosław Sobecki). The dynamics of social change in Central Europe confronts the challenges of education, one of which is to prepare students for life in cultural differentiation. M. Sobecki proposes his own approach to the study of social and cultural identity. The idea of the study is based on the simultaneous consideration of four dimensions of identification: regional and national, religious and European. Together, these measurements constitute the identification profile. As a result of the method the author has singled out 15 types of the identification profile.

Analyzing the Polish scientists research into cultural problems of education, it is impossible not to pay attention to the difference between the content of the concepts of multicultural and intercultural education and the fact that it is the latter which Polish teachers focus on now ${ }^{16}$.

To confirm this opinion, some topics are presented of research in the field of intercultural education in Poland: adaptation of educational reforms to national and ethnic minorities as prospects for intercultural education; intercultural education - political and ideological context, pedagogical idea, social experience and educational practice (Tadeusz Lewowicki); image of tolerance in multicultural education perspective (Stefan Mieszalski); social semiotics and intercultural education (Mirosław Sobecki); methods of modern philosophy in the research foundations of intercultural education (Urszula Morszczyńska, Wojciech Morszczyński); transformation of social and educational policy in the context of intercultural education (Zenon Jasiński); multicultural school - an opportunity to implement intercultural education during I-III year of study at university (Anna Gajdzica); place of religious education in multicultural education policy in Europe (Aniela Różańska); tales of intercultural education for pre-school and primary school children - methodological aspects of sensitivity to the difference (Anna Młynarczuk-Sokołowska).

16 S. Sysojewa: Kulturologiczna koncepcja oświatologii w kontekście rozwoju spoteczeństwa wielokulturowego. „Ruch Pedagogiczny” 2012, nr 1. 
The attention is also paid to the study of field experiences and intercultural education in other EU countries, including such aspects of the problem: the field of intercultural education in Europe today (Jacek Kurzępa); adoption of European trends and standards in educational reforms (Urszula Morszczyńska).

It should be noted that the work of Polish researchers into intercultural education has concerned pedagogical practice with relevant practical recommendations. In this context, there is a significant work of Ewa Ogrodzka-Mazur "The reform of the education and intercultural training in the integrated primary school", in which she carries out a critical analysis of educational reform in Poland since 1999. On its base she isolates positive experiences, problems and prospects of integrated teaching younger learners ${ }^{17}$. Particular attention is paid to training programs and their practical implementation during classes I-III; concept of integrated education; implementation of intercultural education in the integrated education. The scientist gives concrete examples of effective teaching practice and the authors of the best programs of intercultural education, which were implemented by the end of the 90's of the twentieth century in primary school.

The same practical orientation is present in Leandry Korczak's work "Intercultural education in the primary school number 52, Warsaw: integration of the Vietnamese and Polish communities," which highlights areas of practical implementation of intercultural education in a school where children learn Vietnamese ${ }^{18}$. Having lessons and exercises, students become acquainted with Polish and Vietnamese traditions and rituals, learn to show tolerance and respect for others, become aware of their own value and national identity. Classes are not only aimed at expanding students' knowledge of the Polish and Vietnamese culture, but also contribute to the integration of the local Vietnamese community in Polish cultural environment.

17 E. Ogrodzka-Mazur: Reforma systemu edukacji a wychowanie międzykulturowe w zintegrowanym kształceniu wczesnoszkolnym. W: T. Lewowicki, W. Kremień, W. Ogniewjuk, S. Sysojewa (red.): Oswitni reformi: misja, dijsnist', refleksja. Kyjiw 2013, Ministerstwo oswiti i nauki Ukraini, NAPN Ukraini, Wyższa Szkoła Pedagogiczna ZNP w Warszawie, Kyjiwskij uniwersytet imieni Borisa Grinczenka.

18 L. Korczak: Edukacja międzykulturowa w Szkole Podstawowej nr 52 w Warszawie: Integracja społeczności wietnamskiej i polskiej. W: W. Kremień, T. Lewowicki, J. Nikitorowicz, S. Sysojewa (red.): Edukacja w społeczeństwach wielokulturowych. Warszawa 2012, WSP ZNP w Warszawie, UwB. 
The specific feature of Polish studies on multiculturalism is the attention to multicultural environments of borderlands. Significant contribution to the development of ideas of intercultural education, the study of educational problems of ethnic groups in the Polish frontier has been made by famous Polish scientist Jerzy Nikitorowicz, whohas thoroughly researched the educational challenges of the multicultural society in the context of the mythology of the eastern frontier. The book entitled "Ethnic groups in the multicultural world," according to Professor Wojciech J. Burszta is original and atypical as it combines research approaches with encyclopedic knowledge and it reveals the fundamental knowledge about ethnic groups and national minorities in the world ${ }^{19}$.

Another example of cultural traditions of borderland research is the work of Dorota Misiejuk and Jolanta Muszyńska "Cultural traditions in borderland families. Transmission of the national cultural heritage", which examines cultural identity in the situation of historically formed borderlands, where for centuries different cultural groups coexisted ${ }^{20}$. Based on the analysis and interpretation of interviews concerning the type of transmission of culture in certain families, the cultural identity was characterized in the structure of national identity among generations of the Belarusian minority. The value of the work is that the authors describe cultural identity that was studied from generation to generation, which in turn allowed to distinguish three models of socialization, typical of the group of families. In addition to the analysis of the processes of socialization and culturiztion of Belarusian minority families based on individual experiences of different generations, the authors evaluate the social and educational situation of the Belarusian minority in Poland.

What has been highlighted in the works of Polish scholars is the role of the teacher in solving some problems of multicultural societies and the importance of preparation to work in the multicultural environment. Genowefa Koć-Seniuch in her book "Intercultural communication as a special value in teacher education" emphasizes that the current dialogue of cultures in society leads to a multi-dimensional perspective in viewing cultural aspects of teacher training ${ }^{21}$. That is why there is a problem associated with creat-

19 J. Nikitorowicz: Grupy etniczne w wielokulturowym świecie. Sopot 2010, GWP.

20 D. Misiejuk, J. Muszyńska: Tradycje kulturowe w rodzinach na pograniczu. Transmisja dziedzictwa kultury narodowej. W: W. Kremień, T. Lewowicki, J. Nikitorowicz, S. Sysojewa (red.): Edukacja w społeczeństwach wielokulturowych. Warszawa 2012, WSP ZNP w Warszawie, UwB.

${ }^{21}$ G. Koć-Seniuch: Komunikacja międzykulturowa - wartość szczególna w ksztat- 
ing original teacher training programmes, which could become the core of teacher knowledge about tools and competencies that enable effective participation in cooperation with other countries and cultures. The researchers examine intercultural communication in the broadest sense, and they stress that the problem of interpersonal communication is caused by difference in the system of values, attitudes, habits, preferences and prejudices of different ethnic and social groups.

\section{Conclusion}

The analysis of the cultural issues explored in the educational research of Ukrainian and Polish scientists leads to the following conclusions:

- research themes of Polish scientists are concentrated around the problems of multicultural and intercultural education, based on the significant achievements of Polish educators and practitioners in the implementation of cultural approach to education;

- special attention in Polish scientists' studies is paid to multicultural and intercultural education in borderlands; formation of multidimensional identity; different aspects of intercultural education (political, ideological, methodological, organizational, practical, etc.).

- a clear distinction between multicultural and intercultural education, the definition of legislative concepts of national minorities, ethnic groups etc. help to solve the problems of multicultural education in Poland;

- the study of multicultural and intercultural education in Poland is aimed to solve the internal problems of the Polish education and problems related to European integration; a sense of belonging to the European community is certainly a positive and significant value for the Polish society. However, the process of European integration also actualizes finding ways to preserve the identity, culture and traditions of Polish people;

- in Ukraine cultural problems of education are becoming more common and are reflected in pedagogical science and practice. Regarding the issues of multicultural and intercultural education, there is a gradual disengagement of these concepts, and issues of intercultural education

ceniu nauczycieli. W: W. Kremień, T. Lewowicki, S. Sysojewa (red.): Paradygmaty oświatowe i edukacja nauczycieli. Warszawa - Kraków 2010. 
are increasingly more often reflected in research and teaching practice. In the opinion of the author, this is largely due to the intentions of the Ukrainian people to join the European integration;

- the development of Ukraine in the field of research into integrated education - educology and its components and cultural education - is the essential thing for the expansion of cultural issues in educational research;

- culturology of education as a part of educology aimed at studying cultural problems of education and education as a part of culture the unique socio-cultural phenomenon; creating educational and socio-cultural space for the development of humane and tolerant person with multidimensional identity, universal and national values that can exist and work in the global multicultural space.

\section{Bibliography}

Bednarczyk H.: O wielokulturowości pracy i środowiska lokalnego - z doświadczeń edukacyjnej wspótpracy europejskiej. W: W. Kremień, T. Lewowicki, J. Nikitorowicz, S. Sysojewa (red.): Edukacja w społeczeństwach wielokulturowych. Warszawa 2012, WSP ZNP w Warszawie, UwB.

Gajda J.: Wielokulturowość wciaż aktualnym wyzwaniem edukacji humanistyczno-antropologicznej. W: W. Kremień, T. Lewowicki, J. Nikitorowicz, S. Sysojewa (red.): Edukacja w społeczeństwach wielokulturowych. Warszawa 2012, WSP ZNP w Warszawie, UwB.

Gajdzica A.: Zmiana społeczna i opór wobec zmian $w$ badaniach relacji w środowiskach wielokulturowych. W: T. Lewowicki, A. Szczurek-Boruta, E. Ogrodzka-Mazur (red.): Teorie i modele badań międzykulturowych. Cieszyn - Warszawa 2006, UŚ, WSP ZNP w Warszawie.

Grabowska B.: Szkolnictwo wyższe w Polsce w świecie mobilności i zróżnicowania kulturowego. W: T. Lewowicki, W. Kremień, W. Ogniewjuk, S. Sysojewa (red.): Oswitni reformi: misja, dijsnist', refleksja. Kyjiw 2013, Ministerstwo oswiti i nauki Ukraini, NAPN Ukraini, Wyższa Szkoła Pedagogiczna ZNP w Warszawie, Kyjiwskij uniwersytet imieni Borisa Grinczenka.

Koć-Seniuch G.: Komunikacja międzykulturowa - wartość szczególna w ksztatceniu nauczycieli. W: W. Kremień, T. Lewowicki, S. Sysojewa (red.): Paradygmaty oświatowe i edukacja nauczycieli. Warszawa - Kraków 2010. 
Korczak L.: Edukacja międzykulturowa w Szkole Podstawowej nr 52 w Warszawie: Integracja społeczności wietnamskiej i polskiej. W: W. Kremień, T. Lewowicki, J. Nikitorowicz, S. Sysojewa (red.): Edukacja w społeczeństwach wielokulturowych. Warszawa 2012, WSP ZNP w Warszawie, UwB. Lewowicki T.: Oświata $w$ warunkach wielokulturowości - od asymilacji do edukacji międzykulturowej i wielowymiarowej tożsamości. W: W. Kremień, T. Lewowicki, J. Nikitorowicz, S. Sysojewa (red.): Edukacja w społeczeństwach wielokulturowych. Warszawa 2012, WSP ZNP w Warszawie, UwB. Misiejuk D., Muszyńska J.: Tradycje kulturowe w rodzinach na pograniczu. Transmisja dziedzictwa kultury narodowej. W: W. Kremień, T. Lewowicki, J. Nikitorowicz, S. Sysojewa (red.): Edukacja w społeczeństwach wielokulturowych. Warszawa 2012, WSP ZNP w Warszawie, UwB.

Nikitorowicz J.: Grupy etniczne w wielokulturowym świecie. Sopot 2010, GWP. Ogrodzka-Mazur E.: Reforma systemu edukacji a wychowanie międzykulturowe w zintegrowanym kształceniu wczesnoszkolnym. W: T. Lewowicki, W. Kremień, W. Ogniewjuk, S. Sysojewa (red.): Oswitni reformi: misja, dijsnist,' refleksja. Kyjiw 2013, Ministerstwo oswiti i nauki Ukraini, NAPN Ukraini, Wyższa Szkoła Pedagogiczna ZNP w Warszawie, Kyjiwskij uniwersytet imieni Borisa Grinczenka.

Sobecki M.: O diagnozowaniu identyfikacji społeczno-kulturowej w perspektywie edukacji międzykulturowej. W: W. Kremień, T. Lewowicki, J. Nikitorowicz, S. Sysojewa (red.): Edukacja w społeczeństwach wielokulturowych. Warszawa 2012, WSP ZNP w Warszawie, UwB.

Sysojewa S.: Kulturologiczna koncepcja oświatologii w kontekście rozwoju spoteczeństwa wielokulturowego. „Ruch Pedagogiczny” 2012, nr 1.

Борисов В. В.: Теоретико-методологічні засади формування національної самосвідомості учнівської та студентської молоді: Аис. ... А-ра пеА. наук: 13.00.07/В. В. Борисов; Терноп. нац. пед. ун-т ім. В. Гнатюка. - Т., 2006. - 540 с.

Гаврилюк Ж. М.: Методика реалізації культурологічного змісту в курсі історії України 8-9 класах: дис. ... канА. пеА. наук:13.00.02/Гаврилюк Жанна Миколаївна; Ін-т пеАагогіки НАПН України. - К., 2012. - 264 с.

Аекларація прав національностей України [Електронний ресурс]. Режим Аоступу: http://zakon4.rada.gov.ua/laws/show/1771-12.

Етнографічні групи українців [Електронний ресурс]. Режим Аоступу: http://uk.wikipedia.org/wiki/Етнічна_група.

Жорнова О. І.: Теоретико-методологічні засади формування куль- 
туротворчості студентів університетів: Аис. ... А-ра пеА. наук: 13.00.04/O. І. Жорнова; Терноп. нац. пед. ун-m ім. В. Гнатюка. - Т., 2007. -455 c.

Закон України »Про національні меншини в Україні« [Електронний ресурс]. - Режим Аоступу: http://zakon2.rada.gov.ua/laws/show/2494-12. Зеленов Є. А.: Теоретико-методологічні основи планетарного виховання студентської молоді: Аис. ... А-ра пеА. наук: 13.00.07/Є. А. Зеленов; Східноукр. нац. ун-т ім. В.Ааця. - Ауганськ, 2009. - 540 с.

Івашко О. А.: Проблема полікультурної освіти у Республічі Польшуа: Аис. ...канд. пеА. наук:13.00.01/Івашко О. А.; Київ. ун-т імені Бориса Грінченка. - К., 2012. - 260 с.

Перетяга $\Lambda$. Є.: Аидактичні умови формування полікультурної компементності молодших школярів: Аис. ... канА. пеА. наук: 13.00.09/А. Є. Перетяга; Харк. нац. пеА. ун-т ім. Г. С. Сковороди. - Х., 2008. - 274 с.

Тадеуш Аевовицький - учений, педагог, громадський Аіяч: бібліограф.покажч. /УкмаА. і наук.реА.: С. О. Сисоєва, І. І. Сокомова. - К., 2012 - 96 с. Терських $\Lambda$. О.: Культурологічні основи розвитку системи освіти та педагогічної думки на Аонеччині в кіниі XIX-початку XX століття: Аис. ... канд. пеА. наук: 13.00.01/А. О. Терських; Ауган. Аерж. пеА. ун-т ім. Т.Шевченка. - Ауганськ, 2001. - 520 с.

Шевнюк О. А.: Теорія і практика культурологічної освіти майбутніх учителів у вищій школі: Аис. ... А-ра пеА. наук: 13.00.04/О. А. Шевнюк; Нац. пеА. ун-т ім. М. П. Арагоманова. - К., 2004. - 555 с.

Якса Н. В.: Пробесійна підготовка майбутніх учителів до взаємодії суб〉єктів освітнього процесу в умовах полікультурності Кримського регіону: Аис. ... А-ра пеА. наук: 13.00.04/Н. В. Якса; Ін-т пеА. освіти і освіти доросл. АПН України. - К., 2009. - 574 с.

\section{Cultural problems of education in pedagogical research of Ukrainian and Polish scientists}

\section{Summary}

The article deals with the pedagogical research of Ukrainian and Polish scientists which explores the problem of cultural education. It is shown that in Ukraine cultural problems of education are becoming more common, there is a gradual dis- 
engagement of the conceps of multicultural education and the issues of intercultural education are increasingly more often reflected in the research and teaching practice. What seems essential for the expansion of cultural issues in educational research is the development of Ukraine in the field of research into integrated education, educology and its components, cultural education. The research of Polish scientists is based on some significant achievements of Polish teaching science and practice concerning implementation of the cultural approach to education. Special attention is drawn to the studies of Polish scientists on multicultural and intercultural education in borderlands, forming the multidimensional identity, to various aspects of the theory and methods of intercultural education. Solving the problems of multicultural education in Poland contributes to a clear distinction between multicultural and intercultural education, to providing the definition in legal terms of national minorities, ethnic groups, etc.

Key words: multicultural education, intercultural education, human multidimensional identity, national minorities, ethnic groups

Translated by Svetlana Sysoieva 